\title{
Leave politics out of science
}

\author{
Science naysayers have become increasingly vocal in the US government. Attacks on science-whether biological, \\ social or climate-threaten human health, now and in the future.
}

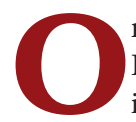
n 30 March, the US House Select Investigative Panel on Infant Lives issued subpoenas to eight medical organizations, requesting that they provide documents identifying all entities and individuals from whom they had procured or to whom they had provided fetal tissue, including all communications related to orders or requests regarding fetal tissue. The panel's chair, Marsha Blackburn, has stated that the group intends to review the practices of the organizations to establish whether any profit is being made from the sale of fetal tissues, which is illegal under US law. But the action is a thinly veiled attempt to curtail research that uses fetal tissues, on the basis of politicians' beliefs that such research is unnecessary and can be accomplished using other tools.

The panel was created in the wake of accusations in 2015 that the nonprofit health-services organization Planned Parenthood was profiting from the sale of fetal tissues, although there is no evidence of any such wrongdoing. Moreover, release of the identifying information requested in the subpoenas risks exposing individuals-including researchers, graduate students, technicians and administrators- to possible violence from antiabortion extremists. Last October, in anticipation of the panel's inquiry, 41 US scientists published an open letter to Congress, supporting the use of discarded fetal tissue in research and citing its crucial role in the development of childhood vaccines. Whether or not the panel's nonbinding investigation eventually succeeds in restricting fetal-tissue research, it is nonetheless having an immediate impact: the supply of fetal tissue has become limited, and some research studies have been halted, according to a report in the New York Times. At a time when, paradoxically, research on fetal microcephaly induced by Zika virus infection is urgently needed, such political maneuvering could have grave consequences for human health.

Climate scientists were not spared from last year's trend of politicians questioning scientific practice. Last June, scientists at the National Oceanic and Atmospheric Administration (NOAA) published a paper in Science reporting that a hypothesized pause in global warming did not exist, according to new analyses of global surface temperatures (Science 348, 1469-1472, 2015). The findings are a blow to climate-change deniers, as they support the conclusion of continued global warming. But instead of stimulating proactive government action against global warming, within weeks of publication, US Representative Lamar Smith, who heads the House Committee on Science, Space and Technology, subpoenaed Kathryn Sullivan, NOAA's administrator. The subpoena required Sullivan to release e-mails and documents pertaining to the work, which Smith suggested was rushed to publication and not subject to rigorous review. Science denies the allegation, which is not supported by the six-month interval between submission and publication. Smith has further asserted that NOAA manipulated data, a charge that the agency refutes. Smith, who has been described as a skeptic of climate change and who has stated that imposing climate-change regulations would undermine the US economy, appears to be seeking to discredit the results of the Science paper through his accusations.
Unfortunately, these congressional actions are just the latest in a series of efforts by some US legislators to politicize scientific research. In 2003, the US House of Representatives convened a hearing on ten grants awarded by the US National Institutes of Health (NIH). The grants included research on HIV transmission among sex workers and HIV/ AIDS in injection-drug users-key at-risk groups for HIV infection-and were among a list of almost $200 \mathrm{NIH}$-funded research grants circulated to Republican members of Congress by a religious lobbying group called the Traditional Values Coalition. Reflecting conservative and religious viewpoints-and not scientific concerns-some Republicans questioned the use of taxpayer money to fund the studies. The NIH director at the time, Elias Zerhouni, defended the grants to Congress. Although no funding was revoked, grant applicants were subsequently advised to expunge their submissions of key words (for example, 'sex workers' or 'needle exchange') to avoid being targeted by future investigations.

Similarly, in 2004, the House approved an amendment to the NIH budget for fiscal year 2005 intending specifically to block the further funding of two grants awarded by the National Institute of Mental Health. These were described by Randy Neugebauer, the US Representative who offered the amendment, as "studying the decorations of dorm rooms and college students" web pages" and "studying what makes for a meaningful day", respectively. The goal of the grants was to increase understanding of issues that affect the mental health of college students. The amendment failed to block the grants' funding, which had already been disbursed, but it set yet another precedent of congressional intrusion into the scientific review process.

And there are potential long-term consequences of politicizing science. A survey of the researchers involved in the 2003 grant controversy reported that most of the responding scientists were more inclined in the immediate aftermath to avoid hot-button terms in their grant applications. Others even ceased work in such fields altogether. The ramifications of experts leaving a field of research because of intimidation tactics cannot be easily quantified. By contrast, some scientists in the survey found that the controversy strengthened their commitment to the research embroiled in congressional oversight (PLoS Med. 5, e222, 2008), lending hope that scientists will continue to stand firm in their current entanglements with Congress.

When politicians decide which disease to fund and which research to endorse on the basis of misconceptions, it ceases to be a winning strategy. Political, social and religious views have no role in sciencefunding decisions or in the validation of scientific research. Although US Congress is responsible for the decision to allocate funds to research, how that money is spent once allocated should be decided by scientists who can expertly assess the potential of a research project and anticipate its impact. The continued politicization of science will impede scientific advances that would stimulate economic, social and medical benefits both in the US and worldwide. Stop politicizing science. 